\title{
EPITHERMAL SYSTEMS AND GOLD MINERALIZATION IN WESTERN THRACE (NORTH GREECE)
}

Michael C.

I.G.M.E. Regional division of eastern Macedonia and Thrace, Brokoumi 30 - Xanthi 67100, conmichael@in.gr

\section{ABSTRACT}

Extensive epithermal systems occur within the Tertiary volcanosedimentary basins of western Thrace northern Greece. Gold deposits or perspective gold districts, related to the above epithermal systems have been recently found in the area. The gold mineralization is of the high - sulfidation type and is associated to a diversity in composition and style volcanic activity.

Sappes epithermal system is the most important (Saint Demetrios and Viper deposits) and has developed in volcanic ocks of intermediate composition accompanied by subvolcanic intrusives (dacite - andesites) and plutonic rocks (quartz - monzodiorites). Saint Demetrios and Viper gold deposits are flat lying and of high sulfidation type mineralizations hosted in hydrothermal breccia zones.

Petrota epithermal system has developed in volcanoclastic and epiclastic rocks (Perama Hill gold deposit), in rhyolites (location Othontoto) and within hyaloclastites and crystal tuffs (location Mavrokoryfi). The mineralized epithermal zones have strong structural control. Perama gold deposit occurs at the intersection of NS and NW trending epithermal zones. These structures represent the higher grade "feeder" system.

Pefka epithermal sys tem is hosted in more acid volcanic vocks (dacites, rhyodacites) and at its southern part (Pasa lofos area) the system is associated with a more alkaline suit (shoshonitic rocks). The mineralized silicifid zones at Pefka mine would correspond to concentric fractures (sheeted fracturing) parallel to the margin of the breccia pipe. The gold mineralization occurs in veins.

In general gold occurs in the form of native gold, gold tellurides or it is associated with enargite, luzonite, tetrahedrite. Advanced argillic alteration and intense silicification are very important for the epithermal systems in western Thrace. A unique low - sulfidation occurrence was found at the central and southern part of Sappes area. Adularia was found in veinlets overlapping argillic alteration zones of high - sulfidation system.

\section{INTRODUCTION}

Gold exploration in Thrace started in 1987 by I.G.M.E. (Institute of Geology and Mineral Exploration) resulted to the discovery of the epithermal systems in Sappes area and the Saint Demitrios gold deposit. It was the first identification of epithermal type of mineralisation in Greece (Michael 1987, 1993). In 1993 the Greenwich resources won the exploration rights of Sappes area and performed an extensive exploration program, which resulted in the discovery of Viper gold deposit (Bridges et. al., 1997).

In Petrota area at Perama Hill, gold deposit was discovered by the companies, Normandy La source, Inmet Mining corp and Silver - Baryte ores Mining Co ( Mc. Alister et. al. 1999, Lescuyer et. al, 2003).

Pefka mine has been explored in the past for copper by underground works and shafts. The initial identification of epithermal style mineralisation in the Pefka area made in the late 1980 (Michael et. al. 1989, Dimou et. al. 1994). 
In this study, we attempt to clarify the nature of the epithermal systems in western Thrace and to present a description of the main epithermal systems in the context of the geological environment, hydrothermal alteration and the mineralogical composition of the ore.

\section{GEOLOGICAL SETTING (REGIONAL GELOLOGY)}

The geological structure of western Thrace (eastern Rhodope zone) comprises three geotectonic units (Fig. 1).

a. The Pre - Mesozoic crystalline basement of highly metamorphic rocks,

b. The Mesozoic Circum Rhodope zone (Makri unit) and

c. The Tertiary basins with volcanic and sedimentary rocks.

The Tertiary basins, comprised of clastic sediments and extensive magmatic rocks (andesites, dacites, rhyodacites, rhy; Jites, shoshonites, latites).

Tertiary granitic bodies and acid dykes intrude these volcanic rocks. The extensive Eocene - Oligocene magmatic activity is connected with continental collision that followed the subduction of African - Arabian plate beneath the Eurasian (Yanev et. al. 1998).

\section{EPITHERMAL SYSTEMS}

Three extensive epithermal systems with gold deposits and perspective gold mineralizations have been identified in the area of the Tertiary volcanosedimentary basins (Fig. 1).

a. Sappes area (Essimi - Kirki - Sappes Tertiary basin).

b. Petrota area (Petrota graben), and

c. Pefka area (Ferrae - Peplos Tertiary basin).

\subsection{Sappes area}

\subsubsection{Geology of the area}

The Sappes area is predominantly covered by calc - alkaline volcanic rocks of intermediate composition (pyroxene - andesites basalt, pyroxene - hornblende andesites), accompanied by subvolcanic dacite - andesites and intrusive quartz - monzodiorite (Michael et. al. 1988, Michael 1993, Fig. 2).

\subsubsection{Hydrothermal alteration}

The epithermal system at Sappes area contains two groups of hypogene alteration minerals, an earlier acid sulphate group (advanced argillic group) and a later group.

During the earlier phase the following alteration zones were formed (Michael et. al. 1988, 1989, Michael 1993, Michael 1995) : a. Siliceous zone (silica caps - silica hydrothermal breccia, vuggy silica), b. Siliceous zone with diaspore, c. Alunite zone, d. Argillic (kaolinite)/ Sericite zone, e. Quartz sericite zone, f. Pyrophyllite zone.

During the later phase adularia is formed at the southern part of the area, overlapping the argillized rocks at the earlier phase (Michael 1993).

Hydrothermal biotite (disseminated biotite or biotite in veinlets) also is found associated with subvolcanic bodies (Voudouris et. al. 1990). This potassium alteration is typical for porphyry type deposits. It is obvious that in the area there is a genetic relationship between high sulphidation and porphyry type deposits. 


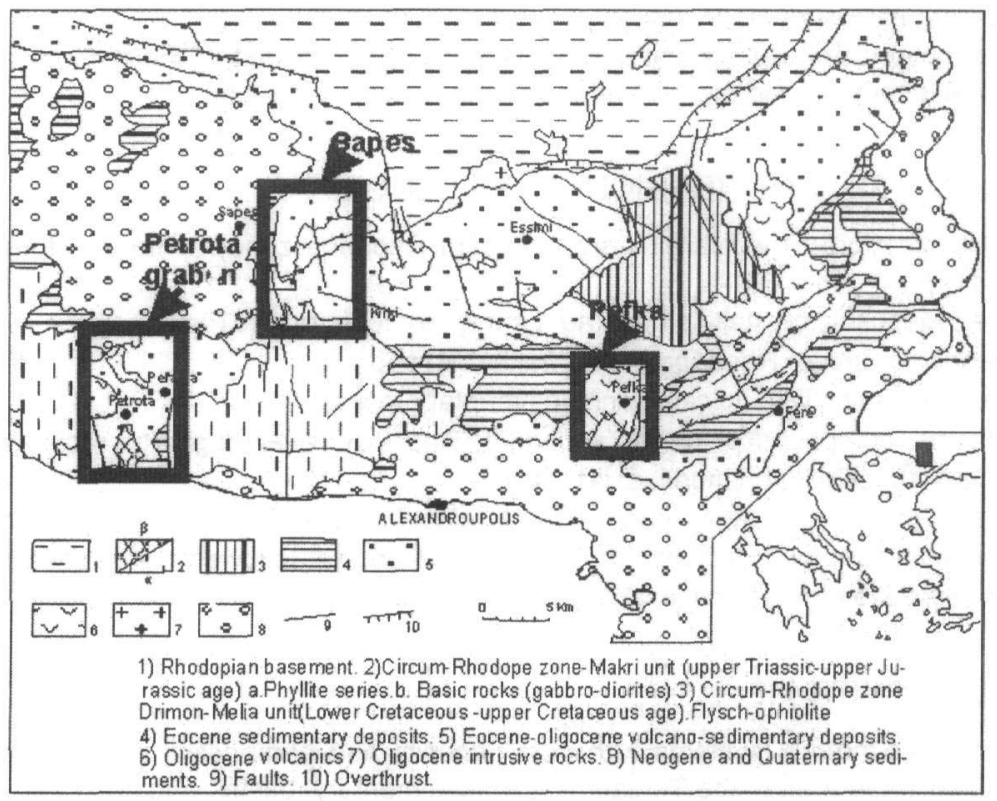

Fig.1 Geological sketch map of Western Thrace. (Papadopoulos P. 1988, modified by Michael C.)

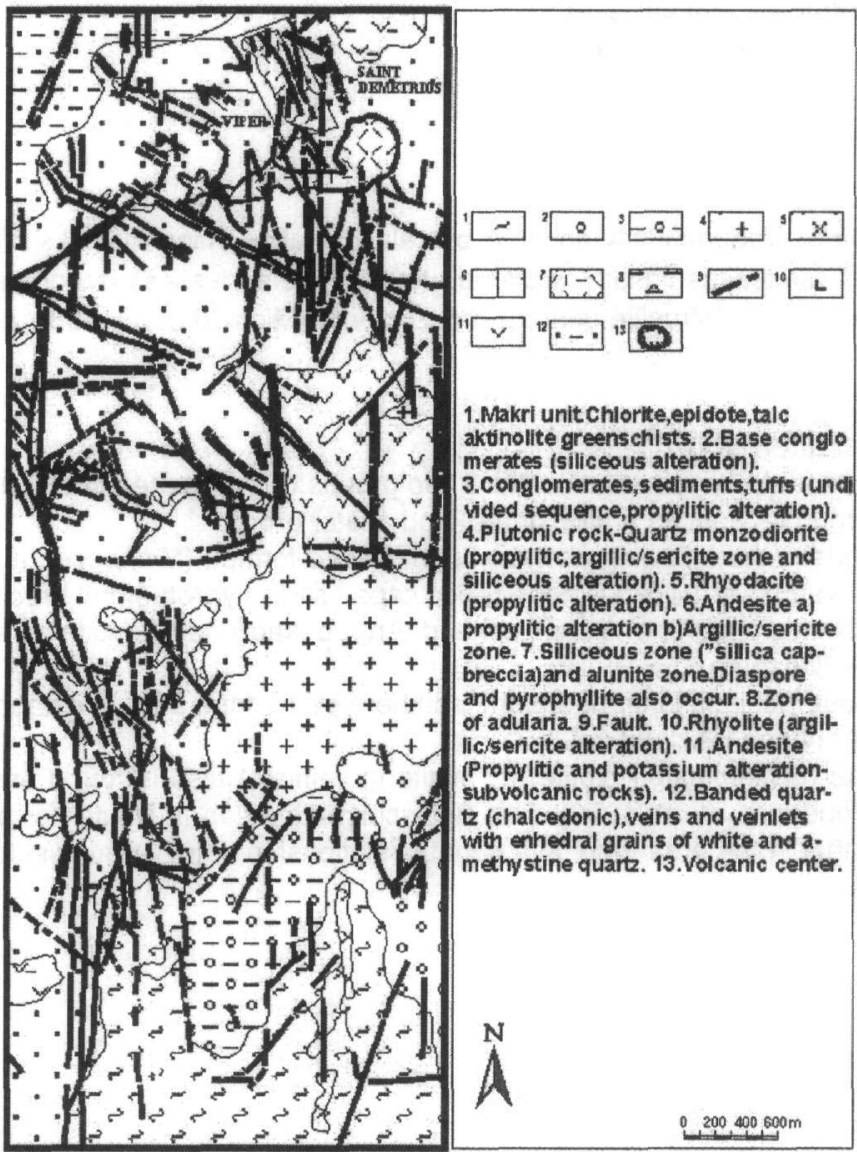

Fig.2 Geological map of Sappes area.(Michael C. 1992) 


\subsubsection{Mineralization}

Mineralisation at Sa it Demetrios deposit occurs on surface in hydrothermal and vuggy silica breccia. Some veintets in the argillic - sericite zone also occur.

Gold occurs in native form and is associated with tellurides, sulphides and sulphosalts (enargite, tetrahedrite and tennantite).

The mineralisation at Saint Demetrios deposit is characterized by three main mineral paragenesis :

a. Quartz - sulphides and tellurides. Characteristic minerals are : quartz ( \pm amethyst), pyrite, arsenopyrite, sphalerite, galena, chalcopyrite, pyrrhotite, marcasite, semseyite, petzite, altaite and tetrad $/$ mite.

b. Quartz - sulfosalts with gold. Characteristic minerals are: quartz, enargite, tetrahedrite, tennantite and gold.

c. Quartz - gold. In this late stage gold - bearing baryte veins were deposited.

The oxidation stage of mineralization comprises hematite, goethite, limonite, covellite, bornite, gypsum, titanite and woodhouseite.

The deposit in Viper area (adjacent to Saint Demetrios area) is connected with north westerly trending zone, which represents a steeply dipping fissure vent system (Bridges et. al. 1997, Border , et. al. 1999). This system formed the initial pathway for mineralising magmatic fluids. Gold occurs in the form of native golu, gold tellurides and more commonly is associated with enargite and tetrahedrite (goldfieldite). Viper and Saint Demetrios deposits are believed to be the same ore body which is separated by late - stage northeasterly trending fault with more than $100 \mathrm{~m}$ vertical offset.

Sulfur isotope data were obtained for galena, pyrite, enargite and sulfide pairs (galena sphalerite) from Viper and saint Demetrios deposits (Cheliotis et. al. 1999).

The $\delta^{34} \mathrm{~s}$ values ranges from $-4.7 \%$ to $+0.6 \%$ (average value $-2.14 \%$ ) for Viper and between $-4.3 \%$ and $+0.3 \%$ (average value $-1.42 \%$ ) for Saint Demetrios.

These values suggest that the bulk of the sulfur in the Sappes epithermal system was derived from "deep - seated" magmatic source.

\subsection{Petrota area}

\subsubsection{Geology of the area}

The area of Petrota is covered by high $\mathrm{K}$ - calcalkaline and shoshonitic volcanic rocks. The volcanic rocks can be divided into three series (Fig. 3):

a. Andesitic (lahars, agglomerate tuffs, lavas and volcanic breccia of andesitic and basaltic andesitic composition).

b. Rhyodacitic - rhyolitic (lithic, agglomerate and lapilli tuffs, crystal rich fragments in pyroclastic rocks, hyaloclastites, pumice tuffs, spherulitic and ignibritic tuffs.

c. Shoshonitic (Trachytic and latitic lava flows, tuffs and breccias).

Minor intrusive bodies (andesites latites and rhyolites) also occur as dykes and domes.

In Perama area at the eastern border (Petrota Hill) of the Petrota graben a significant component of volcanoclastic rocks together with volcanic (andesitic) breccia, epiclastic sandstones with minor mudstones and limestones lenses are developed. 


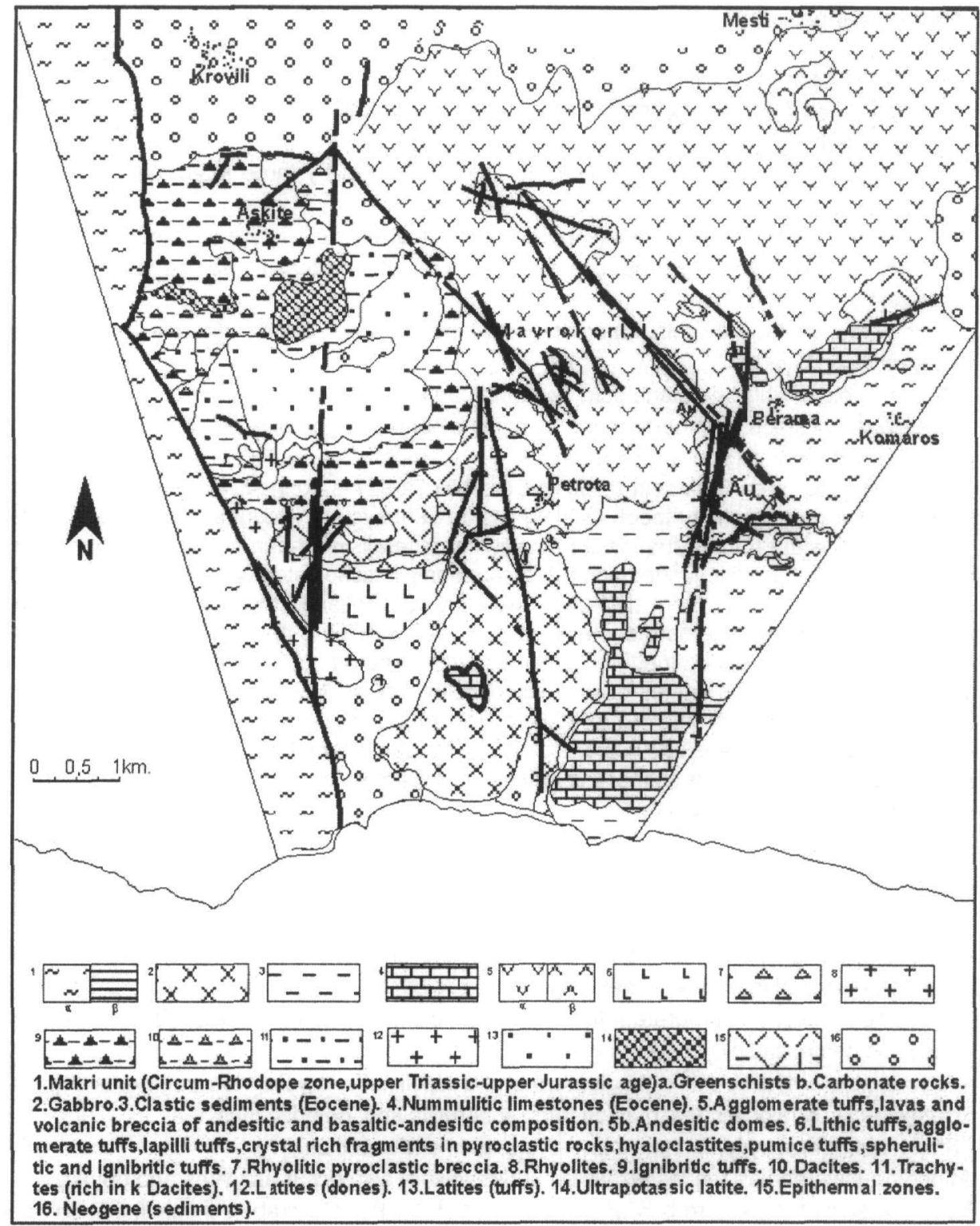

Fig. 3 Geological map of the Petrota area (Michael C. 2002)

\subsubsection{Hydrothermal alteration}

Extensive areas in Petrota graben have been affected by hydrothermal alteration.

At Perama - Vrachos area hydrothermal alteration is also strongly developed and a number of different alteration types have been distinguished.

The siliceous alterat on (silica cap) comprises quartz ( \pm alunite) and it can be divided into massive amorphous chalcedonic and opalitized rocks (Vrachos area) or massive and vuggy silica baryte breccia. (Perama Hill).

Argillic - sericitic alteration is developed at the periphery of the silica caps and covers some square kilometers throughout the Tertiary basin. 
More extensive areas of propylitized rocks are seen in the northern part of the basin and away from the main areas of hydrothermal alteration and mineralization.

At the western part of the area (Othondoto location) hydrothermal alteration zones were developed within rhyodacitic and rhyolitic rocks. The epithermal system is characterized by flat - lying brecciated silica - alunite and advanced argillic alteration at the periphery.

At the central part of the area (Mavrokoryfi location) advanced argillic alteration (kaolinite, alunite, tridymite, opal and quartz) and siliceous alteration (opalitized rocks)are very important.

\subsubsection{Mineralization}

Perama gold deposit (Perama Hill) occurs at the intersection of NS and NW trending epithermal zones. It is evident that these structures represent the higher - grade "feeder" system. Gold mineralisation is associated with a series of wide $(>1,5 \mathrm{~m}$ ) to narrow (few $\mathrm{cm}$ ) milky quartz - baryte veins and stockwork veining in the vuggy silica block. Gold was also found disseminated in the surrounding altered (oxide mineralization) epiclastic sandstones .

At Othondoto the epithermal system is not mineralized at the surface.

\subsection{Pefka area}

\subsubsection{Geology of the area}

The area is covered predominantly by volcanic rocks (Fig. 4)of intermediate (andesites) to acid (dacites, rhyodacites) and shoshonitic rocks (latites, shoshonites). The andesites, dacites and rhyodacites occur in agglomerate tuffs, lava flows, domes and ash - flow tuffs. The volcanic rocks show an overall high $\mathrm{K}$ calcalkaline orogenic affinity. In the southern part of the Pefka area (location Pasa lofos) the epithermal system is associated with more alkaline suite (shoshonitic rocks). In the southeastern part of the area some clastic sediments also occur. In general the geological environment is transitional to subaerial.

\subsubsection{Hydrothermal alteration}

An extensive part of the Pefka area has been stongly hydrothermally altered. Three alteration types can be distinguished: a. siliceous alteration, b. advanced argillic alteration and c. propylitic alteration.

The silicified zones follow structure zones and they have strong structural control. They can be divided in opaline, fine giuartz and chalcedonic quartz silicified zones.

The advanced argillic alteration is strongly developed and creates a halo around the silicified zones. This alteration comprises kaolinite ( \pm alunite).

The propylitic alteration is characterized by epidote, chlorite and carbonate minerals.

\subsubsection{Mineralisation}

Gold and base metal mineralisation in Pefka area occur in veins within silicified zones. The mineralized and silicified zones at Pefka mine would correspond to concentric fractures (sheeted fracturing) parallel to the breccia pipe. The mineralisation is mainly characterized by complex mineral paragenesis. Great number of rare minerals occur, as well as impressive content of some elements such as $\mathrm{Te}, \mathrm{Au}, \mathrm{V}, \mathrm{Sn}$. Gold is associated with enargite, luzonite and tennantite.

\section{CONCLUSIONS}

The western Thrace displays a diversity of epithermal gold deposits related to magmatic hydrothermal systems developed during the Tertiary.

Heat and fluids are released from high level intrusions and channeled up by fault zones and dilational structures (structural control of the mineralization). The initial acid magmatic fluids reacted with country rocks (vuggy silica) and mixed with circulating meteoric water forming high sulfidation mineralizations. The magmatic fluids, which contain dissolved reactive gases, are reduced by rock interaction and dilution by circulating meteoric waters (Simmons 1995). Under these reduced con- 
ditions, low sulfidation type of alteration is formed. By this way it can be explained the overlapping of high sulfidation and ow sulfidation systems at Sappes area. The spatial relationship between high sulfidation system and porphyry type alteration at Sappes area can be explained by a convective hydrothermal system. The release of heat and fluids from high level intrusions and circulating meteoric water create potassic (porphyry systems) and propylitic alteration zones (Corbett et.al. 1977).

Most of the epithermal systems have mineral assemblages and textural features which suggest formation at shallow depth. A new programme to explore these favourable epithermal systems, it will be successful in locating new gold deposits.

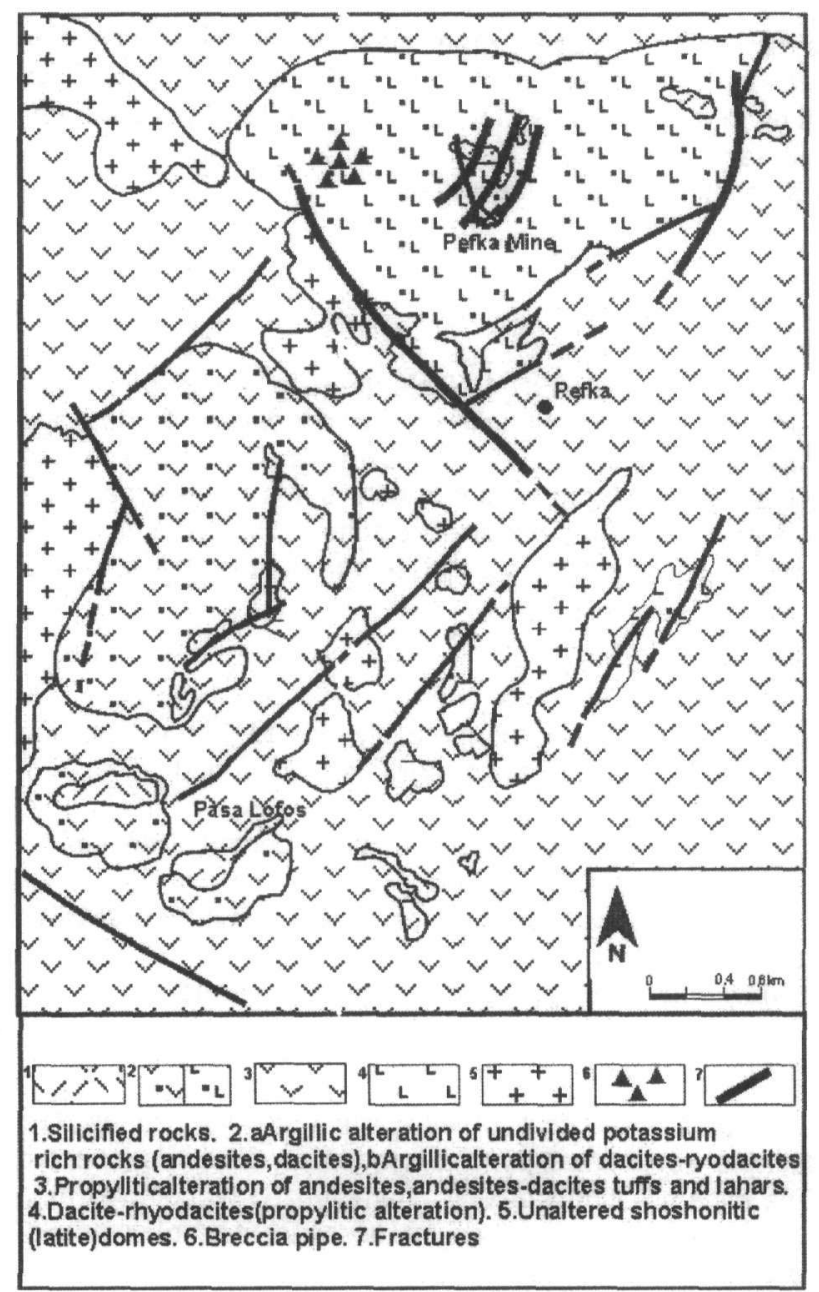

Fig. 4 Simplified geologica' sketch m ap (Michael C.,K.Katirzoglou, 1989 , modified by Micnael C.)

\section{REFERENCES}

Border, A. J. M., Michael, C., Constantinides, D. 1999. Discovery and evaluation of the Sappes gold deposits North - Eastern Greece. Conference Proceedings of new Generation GOLD 99. Perth, Western Australia, 22 - 23 November 1999. 
Bridges, P. S., Gordon, M. J., Michael, C., Ambatzioglou, M. 1997. Gold Mineralisation at Sappes, Northern Greece. In Europe's major gold deposits, Irish Association for Economic Geology, Abstracts volume, 95 107.

Cheliotis, J. Kilias, S., Shepherd, T., Naden., J., Michael, C., Bitzios, D., 1999. Models of epithermal systems in Rhodope area and Islands of Aegean. Internal report of I.G.M.E.

Corbett, G. J., Leach, T. M. 1977. Southwest Pacific rim Gold - Copper systems :

Structure, Alteration and Mineralisation. Short course manual.

Dimou, E., Michael, C., Serment, R., 1994. Mineralogical composition of the epithermal polymetallic mineralisation of Pefka, Rhodope area. $7^{\text {th }}$ Congress Geological Society of Greece, Abstracts.

Eliopoulos, D., Michael, C., Arvanitides, N., Constantinides, D., Katirzoglou, K., Kosmas, C., Demitroula, M. 1989. Primary gold mineralisation in the Greek Rhodope massif. Symposium "Gold 1989 in Europe" in Toulouse, France.

Lescuyer, J. L. , Bailly, D., Cassard, A. L. W. Lips \& Piantone, P. Mc. Alister, M. 2003. Sediment - hosted gold in south - eastern Europe : the epithermal deposit of Perama, Thrace, Greece. Mineral Exploration and Sustainable Development et. al. (eds).

Mc Alister M., Hammond, ․ M., Normand, D. \& Kampasakalis, M. 1999. Discovery case history for the Perama Hill gold deposit, Greece. In : New Generation Gold Mines Conference in Perth, West Aust., 22 - 23 rd Nov $1999: 10 \mathrm{p}$.

Michael, C., Papadopoulos, P., Marantos, I., Evangelou, E., 1988. Epithermal gold mineralisation in Konos area. I.G.M.E., internal report.

Michael, C., Katirtzoglou, K., Perdikatsis, V., Constantinides, D. 1989. The polymetallic mineralisation of the Pefka area, Evros county, Greece. Geologica Rhodopica, $1: 323$ - 39.

Michael, C., Perdikatsis, V., Marantos, I. 1989. Mineralogy of the epithermal gold mineralisation in the Konos area, East Rhodope, Greece. Abstract to the $2^{\text {nd }}$ Hellenic - Bulgarian symposium on the geological and physicogeographical problems of the Rhodope massif.

Michael, C., 1993. Geology and Geochemistry of epithermal gold deposit in Konos area I.G.M.E., internal report.

Michael, C., Perdikatsis, V., Dimou, E., Marantos, I. 1995. Hydrothermal alteration and ore deposition in epithermal precious metal deposit of Agios Demetrios, Konos area, Northern Greece. Geol. Soc. Greece, sp. Publ.., 4/2, : 778 - 782.

Michael C. 1999 Conceptual model of Konos epithermal system. Plate tectonic aspects of Alpine Metallogeny in the Carpatho - Balcan region $3^{\text {rd }}$ annual meeting Athens, Sept. 1995, I.G.C.P. project 356.

Michael, C. 2002. Exploration - Valuation study of primary gold. I.G.M.E., internal report.

Simmons, S. F. 1995. Magmatic contributions to low sulfidation epithermal deposits, in Thompson, J.F.H. ed., Magmas, fluids and ore deposits. Mineralogical Association of Canada, short course handbook, v. $23: 455$ $-478$.

Voudouris, P., Michael, C., Arikas, K. 1990. Ein porphyry - Cu - vorkommen und peripher epithermale alterationen in Kassiteres / Sape (Thrazien, Nordg - Riechenland : Ber. Deutsch. Miner. 1., 271.

Yanev, Y., Innocenti, F., Manetti, P. Serri G. 1998. Upper Eocene - Oligocene collision - related volcanism in Eastern Rhodopes (Bulgaria ) - Western Thrace (Greece) : Petrogenetic Affinity and Geodynamic Significance. Acta Vulganologica - vol 10 (2) - $1998: 279-291$. 